San Jose State University

SJSU ScholarWorks

Master's Theses

Master's Theses and Graduate Research

Fall 2010

\title{
Reproductive Den Habitat Characterization of American Badgers (Taxidea taxus) in Central California
}

Katrina Louise Huck

San Jose State University

Follow this and additional works at: https://scholarworks.sjsu.edu/etd_theses

\section{Recommended Citation}

Huck, Katrina Louise, "Reproductive Den Habitat Characterization of American Badgers (Taxidea taxus) in Central California" (2010). Master's Theses. 3868.

DOI: https://doi.org/10.31979/etd.pyq4-ydce

https://scholarworks.sjsu.edu/etd_theses/3868

This Thesis is brought to you for free and open access by the Master's Theses and Graduate Research at SJSU ScholarWorks. It has been accepted for inclusion in Master's Theses by an authorized administrator of SJSU ScholarWorks. For more information, please contact scholarworks@sjsu.edu. 


\title{
REPRODUCTIVE DEN HABITAT CHARACTERIZATION OF AMERICAN BADGERS (TAXIDEA TAXUS) IN CENTRAL CALFORNIA
}

\author{
A Thesis \\ Presented to \\ The Faculty of the Department of Biological Sciences \\ San José State University
}

In Partial Fulfillment

of the Requirements for the Degree

Master of Science

by

Katrina L. Huck

December 2010 
(C) 2010

Katrina L. Huck

ALL RIGHTS RESERVED 
The Designated Thesis Committee Approves the Thesis Titled

\title{
REPRODUCTIVE DEN HABITAT CHARACTERIZATION OF AMERICAN
}

BADGERS (TAXIDEA TAXUS) IN CENTRAL CALFORNIA

\author{
by \\ Katrina L. Huck \\ APPROVED FOR THE DEPARTMENT OF BIOLOGICAL SCIENCES \\ SAN JOSÉ STATE UNIVERSITY \\ December 2010 \\ Dr. Shannon M. Bros \\ Department of Biology \\ Dr. Susan Lambrecht \\ Department of Biology \\ Dr. Dave Johnston \\ H. T. Harvey and Associates
}




\section{ABSTRACT \\ REPRODUCTIVE DEN HABITAT CHARACTERIZATION OF AMERICAN BADGERS (TAXIDEA TAXUS) IN CENTRAL CALFORNIA \\ by Katrina L. Huck}

The American badger (Taxidea taxus) is a species of special concern in California, and, as such, conservation measures are necessary. The goal of this study was to identify potential reproductive den habitat characteristics in order to more accurately predict critical reproductive habitat in central California grasslands. A paired study design was used to examine differences between reproductive and non-reproductive sites, and logistical regression was used to analyze the variables and produce two predictive models, one with biotic factors and one with abiotic factors. Badgers in central Californian grasslands appear to rely on both biotic and abiotic factors when selecting locations for reproductive den sites. Predictive biotic variables included amount of ground vegetation, presence of predators, presence of prey, and nearest shrub width. Predictive abiotic variables included distance to a drainage point and slopes at 10, 30, and $40 \mathrm{~m}$ from the den entrance. Integrating information from these models into conservation efforts will identify critical reproductive habitat and help form viable conservation strategies for the species. 


\section{ACKNOWLEDGEMENTS}

Thank you to my husband Andrew Huck for his assistance in the field and his support throughout my schooling. Thank you to Lance Freihofer, Carmel de Bertaut, Rachel Roberts, Beth Dawson, Jeff Wilcox, Adam Remmel, Joshua Goodwin, Vi Khuu, and Jonathan Roberts for their assistance in the field. Thank you to Larry Young of SJSU, for his help with the IACUC process. Thank you to Gary Pereir for helping with GIS modeling attempts. Thank you to Key Agricultural Services, Inc. for providing me a discounted rate for soil texture analysis. Thank you to my committee: Shannon Bros, Dave Johnston, and Susan Lambrecht for their critiques and patience with the thesis process. Thank you to Mary Krakow for editing the thesis for grammar. Thank you to Elaine Alper for help with formatting. Thank you to Marge Petersen for providing housing during my schooling.

Thank you to the parks and the employees at the parks who granted me permission to survey and record data on their lands: MidPeninsula Regional Open Space District, Blue Oak Ranch Reserve, Fort Ord BLM, Palo Alto City, San Jose Open Space Authority, Santa Clara County Parks.

This research was supported in part by the Michael Lee Environmental Foundation and the Arthur and Karin Nelson Scholarship. 


\section{TABLE OF CONTENTS}

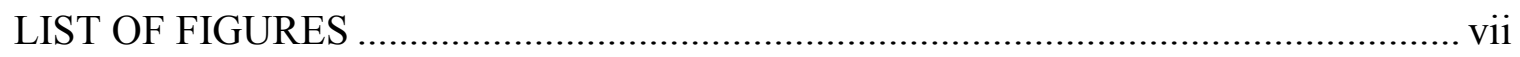

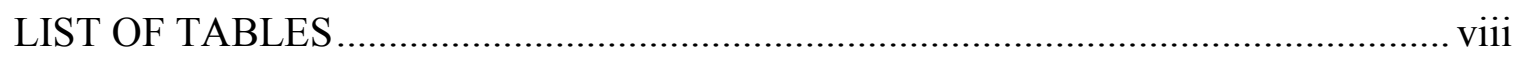

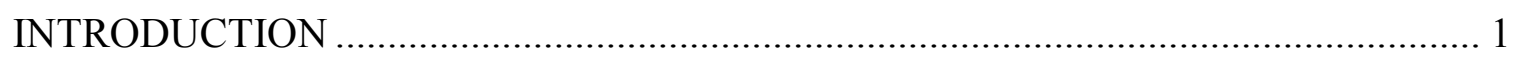

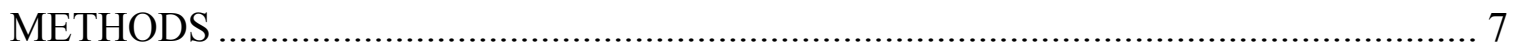

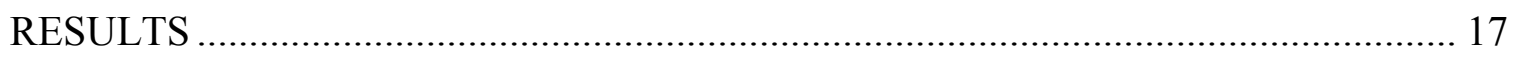

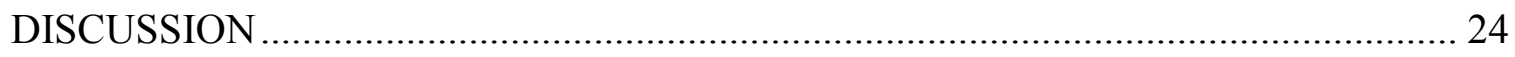

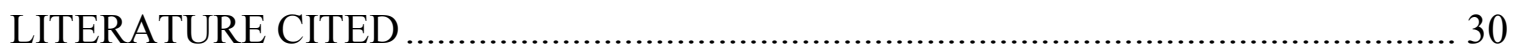




\section{LIST OF FIGURES}

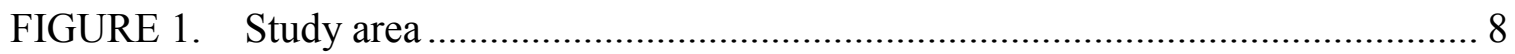

FIGURE 2. Relative arrangement of paired sites at a location................................ 10

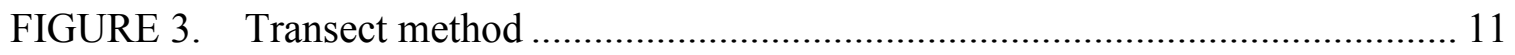

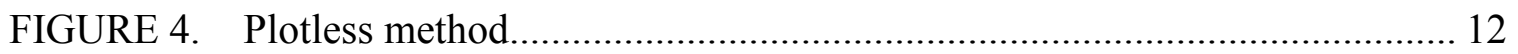

FIGURE 5. Midpeninsula Regional Open Space District contained six

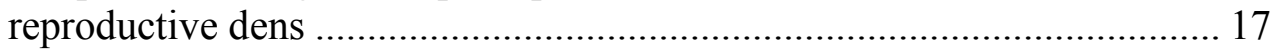

FIGURE 6. Blue Oak Ranch Reserve contained four reproductive dens .................... 18

FIGURE 7. Ford Ord contained four (one active) reproductive dens ........................ 19

FIGURE 8. Logistic regression model classification success for biotic factors............ 20

FIGURE 9. Mean values for biotic characteristics for reproductive and non-reproductive dens included in the logistic regression model ............. 21

FIGURE 10. Logistic regression model classification success for Abiotic factors ......... 22

FIGURE 11. Mean values for Abiotic characteristics for reproductive and nonreproductive dens included in the logistic regression model ................... 23 


\section{LIST OF TABLES}

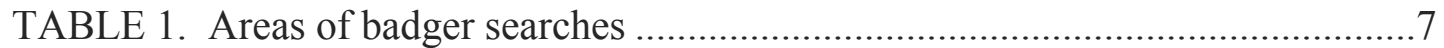




\section{INTRODUCTION}

Populations of the American badger (Taxidea taxus) are declining (Williams 1986), and it has been specified as a special status species in many parts of Western North America. In Canada, where the most extensive studies of T. taxus have been conducted, the badger is included on the following lists (Scobie 2002): Concerned (Yellow list Alberta), Critically Imperiled (British Columbia), Rare-uncommon (Saskatchewan), and threatened (S2 - Ontario). In the United States, the badger has been listed as a mammalian Species of Special Concern in California (Williams 1986) and endangered in Indiana (Sullivan 1996). In Mexico it is considered threatened (Fernandez et al. 2007). To effectively evaluate reasons for the decline, it is essential to understand the extent of their current distribution, their habitat preferences, prey preferences, movement patterns, and the factors affecting reproductive success.

Badgers are opportunistic feeders, and dietary preferences appear to vary with prey availability. Although small fossorial mammals make up most of their diet, other prey items are also consumed. Several studies (Verbeek 1965; Anderson \& Johns 1977; Murie 1992; Verts \& Carraway 1998) indicated that fossorial mammals, such as yellow-bellied marmots and Columbian ground squirrels, are a substantial portion of badger diet. One study (Azevedo et al. 2006) suggested badgers have a high level of dietary overlap with coyotes as well as a lower level of dietary overlap with foxes, raccoons, and skunks; the amount of overlap fluctuates annually and includes prey items such as mammals, amphibians, birds, eggshells, and wheat seeds. Verts \& Carraway (1998) also stated that birds, eggs, snakes, amphibians, and plant material were included in badger diet. 
Badgers use a wide variety of habitat types and can be found from valley floor to alpine habitats, including prairie grassland, sagebrush, open woodlands, and near riparian habitats, generally with an open canopy and dry conditions (Sullivan 1996; Verts \& Carraway 1998). Recent studies in California have identified some habitat characteristics for badger populations in central California. On a state-wide scale, Quinn (2008) found historic and current badger sightings in a variety of habitats including several grassland and shrub types, but also locations associated with hardwood woodlands, conifer woodlands, and conifer forests. Higher elevation and terrain diversity were also good indicators of badger sightings. On a more regional scale in central California, Quinn (2008) found a preference for intermediate slopes (5\% to 50\%) with dens associated with loamy soils with native grassland and scrub habitats. Quinn (2008) also observed nondenning use of annual grassland, maritime chaparral, and oak woodland habitats by badgers. Lay (2008) compared historical and current locations of badgers in central California, and found a decrease of presence at historical locations. Diamond (unpublished data) found loamy soil, sagebrush, and slopes between 5 and $15 \%$ at badger road kill locations.

Factors affecting movement and dispersal patterns of the American badger are largely unknown. Sargeant \& Warner (1972), Murie (1992), Hein \& Andelt (1995) and Goodrich \& Buskirk (1998) have shown that badgers' habitat use varies seasonally within their home range. Diamond (unpublished data) has shown that, in central California, badgers are likely to be found at road crossings more often when soil is loamy, sagebrush is present, and slopes are between 5 and 15\% (Diamond, unpublished data). 
Reproductive females are known to use the same reproductive areas from year to year (Quinn 2008), although offspring generally do not use the natal area past reproductive age (Waser \& Jones 1983). Long (1973), Hoodicoff (2003) and Jager et al. (2006) have shown that badgers are born approximately in late March and early April and leave the natal den in late June and early July. Sullivan (1996) suggested erratic juvenile dispersal, and Messick (1987) suggested juveniles use different corridor habitat than adults, but the underlying mechanisms for direction of movement is unknown. Once these habitat characteristics are known, ecosystem management practices may include protection of reproductive habitat where it was unprotected before.

Successful conservation efforts require known habitat characteristics associated with reproductive dens, which are one of the four types of badger burrows (foraging, day-use, over-wintering, and reproductive) (Verts \& Carraway 1998). Reproductive dens are more complex than day-use dens, with the mound of soil excavated more than twice the size of a day-use den mound (Lindzey 1976; and Weir \& Hoodicoff 2002) and with the burrow as deep as $2.3 \mathrm{~m}$ (Lindzey 1976) and as long as $10 \mathrm{~m}$ (Scobie 2002). Hoodicoff (2003), Lindzey (1978), Weir \& Hoodicoff (2002), Kinley \& Newhouse (2008), and Messick (1987) all suggested badgers dig an initial natal den and then some mothers move kits to a maternal den; hereafter, these are collectively referred to as reproductive dens. Digging an additional maternal den remains consistent with other Mustelid species such as the wolverine (Magoun \& Copeland 1998), river otter (Gorman et al. 2006), and striped skunk (Lariviere \& Messier 1998). Therefore, I expect to find multiple reproductive dens in fairly close proximity to one another in areas where mother badgers 
move kits to a maternal den. Reproductive females are known to use the same reproductive areas from year to year (Quinn 2008), although offspring generally leave the reproductive area after they reach reproductive age (Waser \& Jones 1983). In the springsummer, the mother badger and her kits live in a more extensive den (reproductive) than any of the other burrow types and will not dig many burrows until the kits are old enough to move around (Verts \& Carraway 1998).

Because badgers use different parts of their home range for different purposes in each season (Sargeant \& Warner 1972; Murie 1992; Hein \& Andelt 1995; Goodrich \& Buskirk 1998), it is likely that reproductive den locations are selected for their specific habitat characteristics. However, previous examinations of habitat requirements and badger presence in California (Quinn 2008; Lay 2008; Diamond unpublished data) did not differentiate among burrow types. These studies included foraging and day-use burrows as well as those from migrating males, and were not specific to reproductive dens. If there are specific habitat characteristics associated with badger reproductive dens, ecosystem management practices may include protection of reproductive habitat. The required reproductive habitat characteristics identified in this study will provide information for rapid relocations or reintroductions should they become essential for the survival of the species.

The purpose of the present study is to determine if there are specific habitat characteristics associated with the reproductive dens of the American badger (Taxidea taxus) in hilly grassland areas in central California. By comparing actual reproductive den sites with sites nearby, I expect to determine if differences in habitat characteristics 
can be detected between sites selected for reproductive dens and sites not selected for reproductive dens. These sites will be paired, with a distance between reproductive and non-reproductive sites that would be close enough for the mother badger to make a choice between the two sites to dig her reproductive den. In this study, categories for possible characteristics criteria include ease of burrowing, predator detection, prey detection, and landform characteristics associated with reproductive dens.

Reproductive dens are extensive tunnels (Lindzey 1976; Weir \& Hoodicoff 2002), not just short linear tunnels in the ground like the day-use burrows. Therefore, ease of burrowing may play a more significant role in reproductive den locations than in day-use locations. Soil texture and penetrability may be the most limiting factors for ease of burrowing large reproductive dens. These factors may affect the likelihood that a significant den formation can be supported for an extended period of time. If burrowing is a consideration in reproductive den site selection, I would expect to find higher soil penetrability and more friable soils at reproductive sites. Local topography may affect prevailing wind direction so mothers may better detect predators. I would expect to find drainage types that promote prevailing wind direction toward reproductive sites. The aspect of the burrow may be important due to the warming affect of the sun and for predator detection by scent. I would expect to find reproductive sites on south-facing slopes. The slope of the location may be important for drainage after a rain. Slope may also affect soil texture with more favorable soil characteristics up-slope or down-slope, with fine soils being washed downhill. I would expect to find reproductive sites on moderate slopes being steeper closer to the site. 
Biological factors may also affect the suitability of a site for a reproductive den. Shorter grasses or native bunch grasses, as opposed to dense non-native annuals, may allow a mother badger to utilize her poor eyesight more efficiently to detect predators, and these grasses may be easier for kits to run through to get back to the reproductive den. I would expect to find reproductive sites in shorter, less dense grasses than the surrounding area. Additionally, shrub cover may provide protection from avian predators for playing kits as well as provide possible habitat for potential prey. I would expect to find reproductive sites moderately close to cover such as shrubs. Distance to another habitat type may be important for housing prey that may live in woodland but forage in grassland habitats. I would expect to find reproductive sites moderately close to other habitats such as chaparral or woodland. Distance to water may be important for hydration. I would expect to find reproductive sites moderately close to sources of water.

Coyotes and badgers forage in close proximity (Minta et al. 1992; Michener 2004); however, little is known about the function of these activities when near badger core habitats or reproductive dens. Because of possible competition between badgers and other carnivores near reproductive dens, I would not expect a badger reproductive site to be close to large prey populations or in another carnivore's core habitat due to the increased possibility of juvenile mortality and competition for prey. 


\section{METHODS}

The study was conducted in central California grasslands with a Mediterranean climate characterized by warm dry summers and cool wet winters and mostly dominated by non-native grasses. Study sites ranged from open grassland to open woodland. The locations for this study were on lands owned by Midpeninsula Regional Open Space District (Monte Bello, Russian Ridge, Los Trancos, and Rancho San Antonio), Santa Clara County Open Space Authority (Rancho Canada del Oro and Sierra Vista), Palo Alto City (Foothills Park and Pearson-Arastradero Preserve), University of California (UC) Berkley (Blue Oak Ranch Reserve), Bureau of Land Management (Fort Ord), and Santa Clara County Parks (Joseph D. Grant County Park) (Fig. 1; Table 1).

Table 1. Areas of badger searches

\begin{tabular}{|c|c|c|}
\hline Area Searched for Badgers & $\begin{array}{l}\text { Badgers } \\
\text { Present }\end{array}$ & $\begin{array}{l}\text { Reproductive Den } \\
\text { Present }\end{array}$ \\
\hline Blue Oak Ranch Reserve (Berkley) & yes & yes \\
\hline Fort Ord (BLM) & yes & yes \\
\hline \multicolumn{3}{|l|}{ Mid-Peninsula Open Space District } \\
\hline Monte Bello & yes & yes \\
\hline Russian Ridge & yes & yes \\
\hline Los Trancos & no & no \\
\hline Rancho San Antonio & no & no \\
\hline \multicolumn{3}{|l|}{ Palo Alto City Parks } \\
\hline Foothill Park & yes & no \\
\hline Arrastrodero Park & yes & no \\
\hline \multicolumn{3}{|l|}{ POST } \\
\hline Rancho San Vicente & no & $\begin{array}{l}\text { no, did not search entire } \\
\text { park }\end{array}$ \\
\hline \multicolumn{3}{|l|}{ San Jose Open Space Authority } \\
\hline Rancho Del Oro & no & $\begin{array}{l}\text { no } \\
\text { no, did not search entire }\end{array}$ \\
\hline Sierra Vista & no & park \\
\hline \multicolumn{3}{|l|}{ Santa Clara County Parks } \\
\hline Grant Ranch Park & yes & no \\
\hline
\end{tabular}




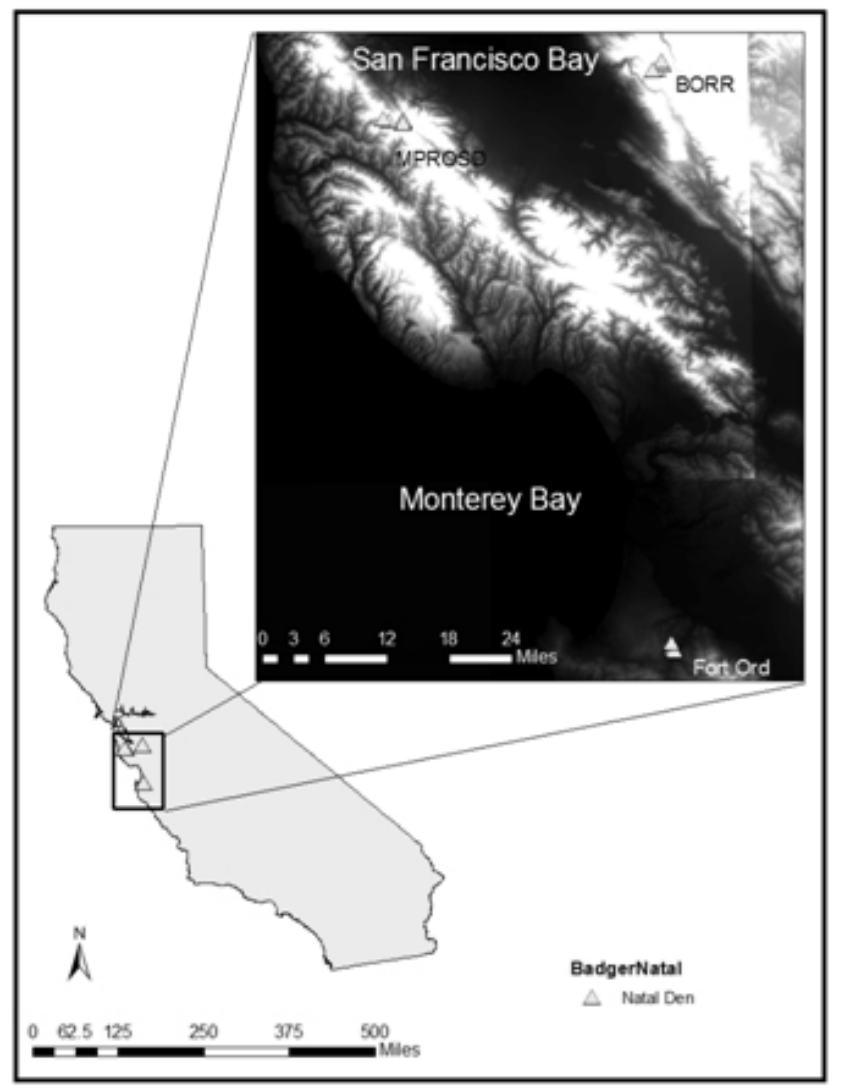

Figure 1. Study areas: Study areas were located in central California. These included lands owned by Midpeninsula Regional Open Space District (Monte Bello, Russian Ridge, Los Trancos, and Rancho San Antonio); Santa Clara County Open Space Authority (Rancho Canada del Oro and Sierra Vista); Palo Alto City (Foothills Park and Pearson-Arastradero Preserve); UC Berkley (Blue Oak Ranch Reserve); and Santa Clara County Parks (Joseph D. Grant County Park).

Study sites were located by searching areas in which badgers had previously been reported (Lay 2008, Quinn 2008), sightings (Delgado, B., Fort Ord BLM, 2009, pers. comm.; Wilcox, J., 2008, pers. comm.), and in grassland habitat which is known to be a preferred habitat type (Sullivan 1996). Study areas were restricted to locations for which permits could be obtained. Areas were methodically searched for reproductive badger burrows via wandering transects in grassland habitats (Miller, R., Oregon State University, 2005, pers. comm.) from November 2008 to November 2009, with habitat 
measurements taken from November 2009 to January 2010. Badger reproductive dens were differentiated from day-use burrows by the amount of soil present at the entrance to the burrow (Lindzey 1976; Scobie 2002; Weir \& Hoodicoff 2002). At Blue Oak Ranch Reserve, one reproductive den identification was enhanced by prior reports of kits by UC Berkley staff. A reproductive site was designated as the habitat within a radius of $40 \mathrm{~m}$ from the den location. GPS coordinates were recorded for each reproductive den.

Habitat characteristics of reproductive dens were compared to those for nearby sites without dens in a paired sample design. Non-reproductive site locations were selected close enough to reproductive sites $(80 \mathrm{~m})$ that a badger could have made a choice in den location. A non-reproductive site was defined as a circular habitat within a $40 \mathrm{~m}$ radius, the center of which was located $80 \mathrm{~m}$ from the reproductive den in a random compass heading (Fig. 2). Constraints on the location were that the non-reproductive sites must be in grassland and not overlap with a pre-existing site. If these stipulations were not met, a new random direction was selected. 


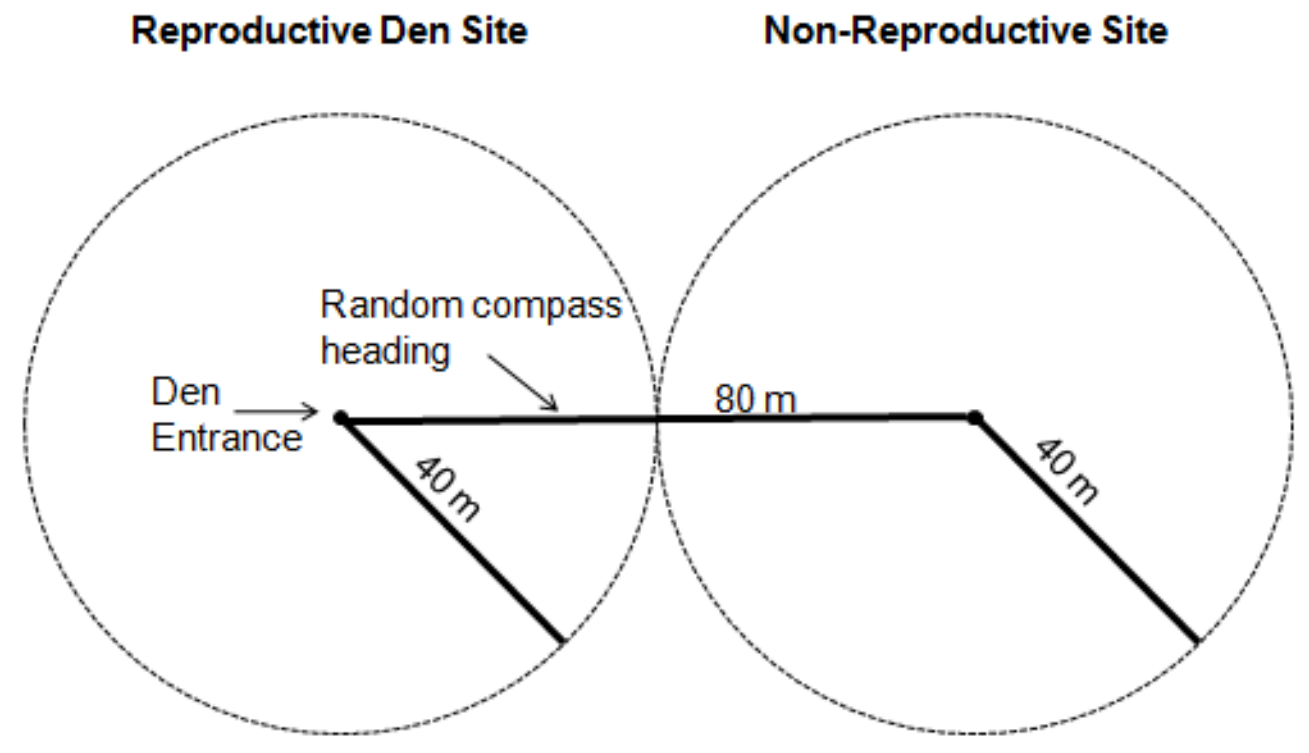

Figure 2. Relative arrangement of paired sites at a location: each with a $40 \mathrm{~m}$ radius, of reproductive dens and random sites $80 \mathrm{~m}$ apart in a random direction, with the stipulation that the random site did not overlap with another site, and that the center was in grassland.

At each reproductive and non-reproductive site, two sampling schemes were used to assess habitat characteristics. The first scheme (hereafter referred to as the transect method) involved four transects radiating outward from the center of the site. At reproductive den sites, the first transect was aligned with respect to the aspect of the den entrance (downhill). Each successive transect was oriented $90^{\circ}$ to the previous transect (Fig. 3). At non-reproductive den sites, the arrangement of the transects was identical to that of the reproductive den site, with the exception that the first transect was oriented downhill from the center of the site, as was consistent with reproductive dens. Flags were placed to mark the site and were removed after the site measurements were collected. At two meter intervals, $1 \times 2 \mathrm{~m}$ plots were set up along each transect with the $0 \mathrm{~m}$ transect included only in transect 1 (Fig. 3). The second scheme (Krebs 1999) 
(hereafter referred to as the plotless method), involved taking measurements of the distance from the center of the site to the nearest object of interest (e.g., prey sign, carnivore sign, or vegetative cover) in each of four quadrants (with a maximum radius of $40 \mathrm{~m})$. The transect lines from the transect method delineated the quadrants for these quadrant measurements (Fig. 4).

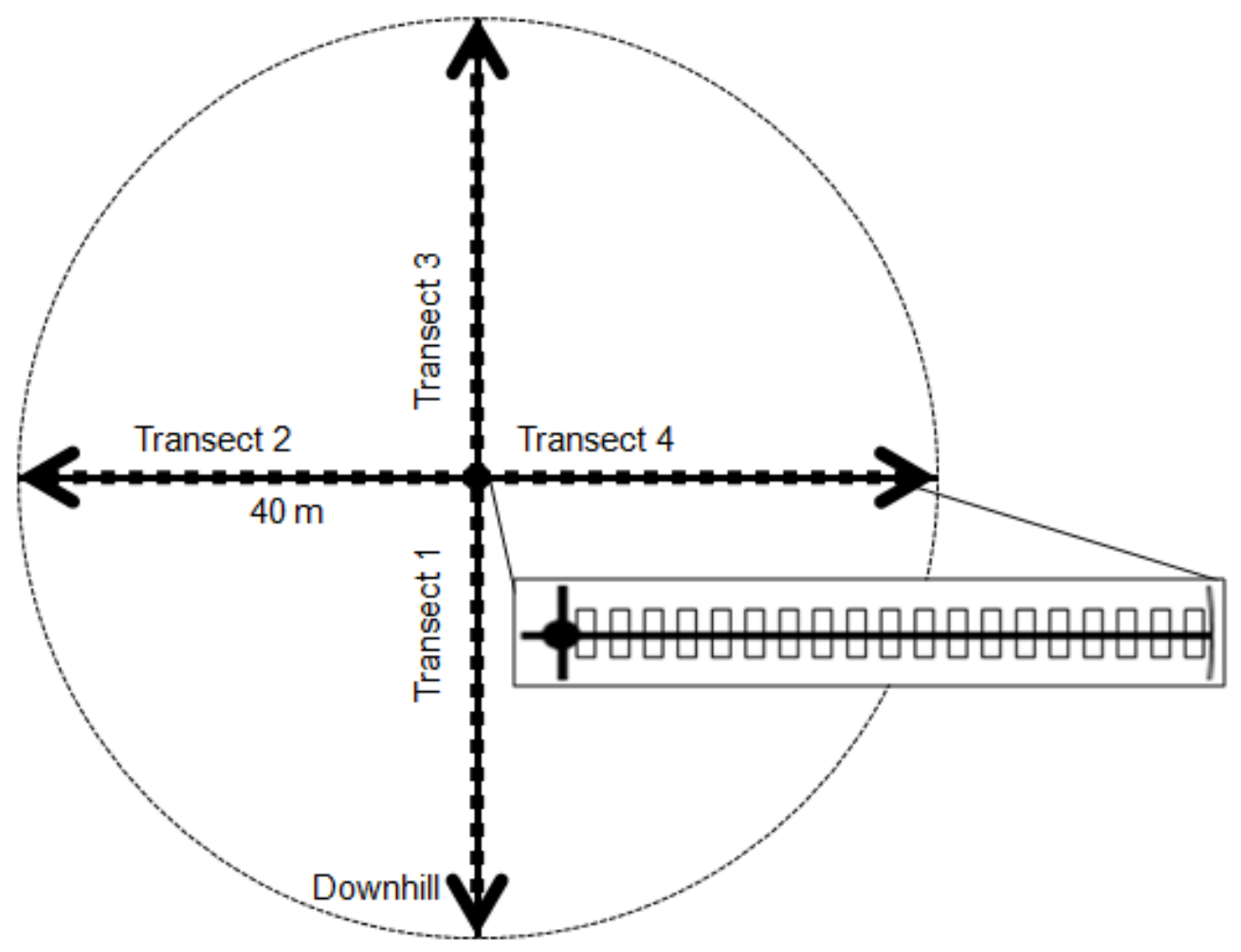

Figure 3. Transect method: Four orthogonally arranged $40 \mathrm{~m}$ transects were included at each site, with transect 1 oriented downhill from the center of the site. At 2 meter intervals along each transect, $1 \times 2 \mathrm{~m}$ plots were set up such that the long dimension was oriented perpendicular to the transect line. Carnivore sign, prey sign and vegetative cover were assessed in each plot. 


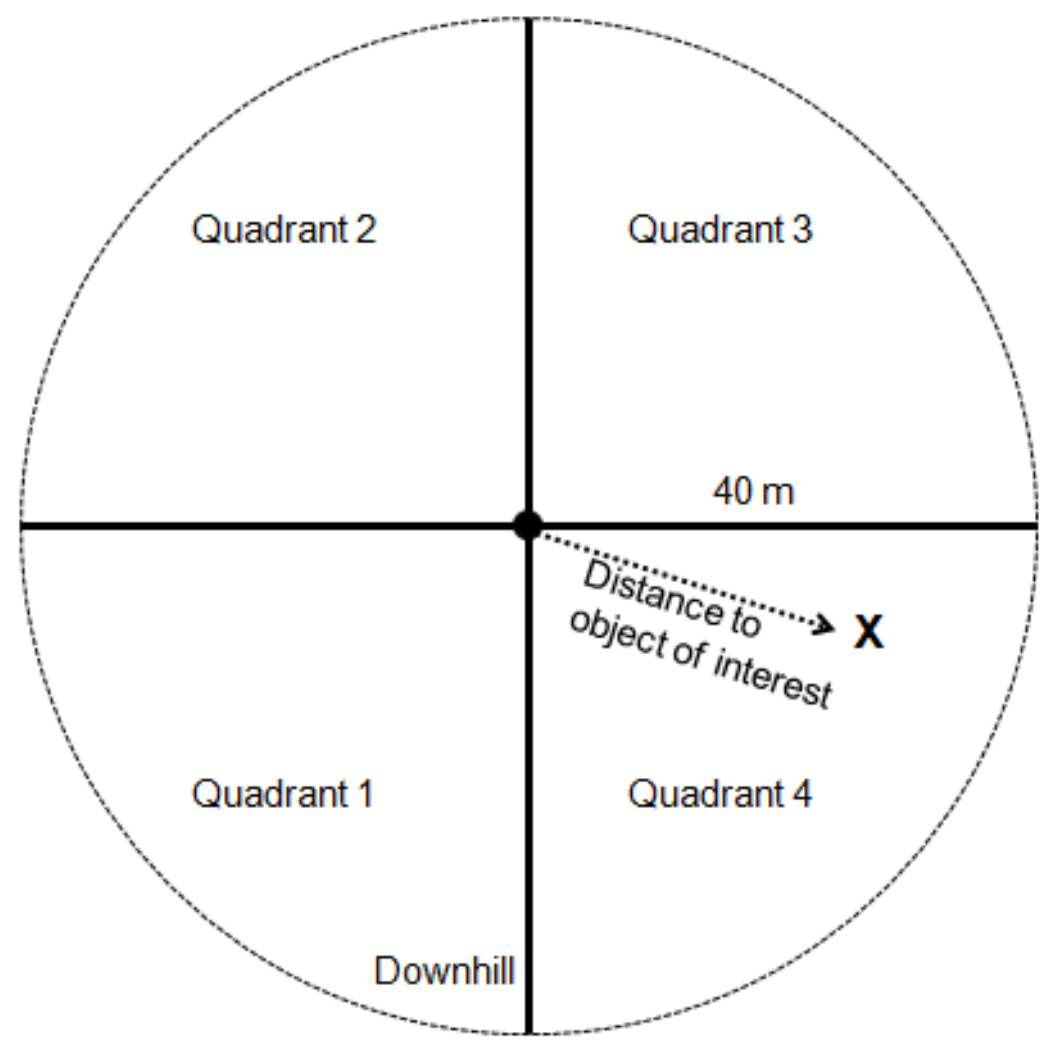

Figure 4. Plotless method: Four quadrants were set up between the 4 transects for the quarter plotless method and distance measurements.

At each site, habitat characteristics relating to both biotic and abiotic factors were measured. All measurements were taken during the day, so as not to disturb any denning badgers, which are nocturnal. Biotic categories included ease of prey detection, ease of other carnivore detection, and vegetative cover. Abiotic categories included ease of burrowing, position on the slope, variables relating to water, and variables relating to sun exposure.

There were several measurements for assessing prey and predator detection. First, prey and carnivore sign counts were made within each $1 \times 2 \mathrm{~m}$ plot along each of the four transects. Then the plotless method was used to assess density of prey and carnivore sign 
using a maximum radius of $40 \mathrm{~m}$; if sign was present in a quadrant, then the distance from the burrow was recorded. If carnivore sign was present, then the heading from the center of the plot to the sign, as well as whether the quadrant was uphill or downhill from the center, were recorded. The plotless method was also used to determine density of other carnivore dens within the $40 \mathrm{~m}$ radius. In order to assess predator detection via scent from the wind to the den, wind direction relative to transect direction was determined with a windsock at the center of the site for a subset of sites.

Several measurements associated with vegetation cover were made. Canopy cover was measured at $0.5 \mathrm{~m}$ above ground level with a canopy densiometer placed parallel to the ground at $20 \mathrm{~m}$ along each of the four transects and at the center of the site. Within the site, the plotless method was used to measure the distance to the nearest shrub, nearest grass patch, and the next nearest grass patch, and non-grassland habitat patch. Maximum height and width were measured for each grass patch and shrub.

Two measurements were made to assess ease of burrowing. Soil penetrability $\left(\mathrm{kg} / \mathrm{m}^{2}\right)$ was measured with a pocket penetrometer to the immediate right of site center when facing downhill. Soil from the center of the site was collected for soil texture analysis (percent sand, silt, and clay), which was conducted by Key Agricultural Services, Inc.

Three measurements were used to assess the position of the site center on the slope. An inclinometer was used to measure slope measurements at $0 \mathrm{~m}$ and every $10 \mathrm{~m}$ along each transect. Aspect at site center was measured with a standard compass. Distance to the bottom and to the top of the hill from the site center was measured with a rangefinder 
(Ranging® Company, East Bloomfield, NY). If the distance was less than $20 \mathrm{~m}$, the rangefinder measures were inaccurate and the distance was measured with a $100 \mathrm{~m}$ tape measure.

Variables relating to water availability were assessed by three types of measurements. Distance to the nearest water source was measured from the center of the site with a tape measure. If no water was located within the site, the site was assigned the maximum observable distance within a site $(40 \mathrm{~m})$. A tape measure was used to determine the distance to the lowest drainage point within the site. Drainage type was classified into three categories based on regression analysis of field data: if slope was increasing away from the center for all four transects, the site was classified as concave; if slope was decreasing away from the center for all four transects, the site was characterized as convex; otherwise, the site was classified as a flat slope. Sites were examined with ArcScene ${ }^{\mathrm{TM}}$ (ESRI, Redlands, CA) as a 3-D image to verify drainage type classification.

Two measurements were made to assess various parameters associated with den position. The aspect of the site center was used as a relative measure of available sun exposure, and was measured with a compass. Position on a hill was characterized as one of six categories, with 1 indicating closest to the bottom and 6 indicating closest to top of the hill. These categories were determined by measuring the distance from the bottom to the top of the hill with a rangefinder (or a tape measure when the distance was less than $20 \mathrm{~m}$ ) then dividing that by six to obtain the length of each category. 
Data obtained from the transect method were summarized as distance bands from the center of the site. Because the amount of data for each plot was small, plots were combined to produce four bands (2-10 m, 12-20 m, 22-30 m, and 32-40 m). For each band within a transect, measures of carnivore sign counts, prey sign counts, and percent ground vegetation from the $1 \times 2 \mathrm{~m}$ plots were added and then averaged across all transects. Slope and densiometer measures were averaged across transects prior to analysis. Slope at $0 \mathrm{~m}$ was not included in the analysis due to the den mound at reproductive sites possibly skewing the data.

Data obtained from the plotless method were averaged over each site for subsequent analyses. The distance measures for each of the variables were averaged prior to analysis which included: nearest carnivore sign, prey sign, distance to the nearest shrub, shrub width, shrub height, distance to grass and to the next grass. For statistical purposes, compass headings were converted to a Cartesian coordinate system represented by two axes and indexed from 0 to 180, South-North and West-East, for aspect and carnivore sign located using the plotless method. The two heading indices and position of the carnivore sign relative to the burrow, uphill or downhill were averaged for the site.

Two separate hierarchical stepwise logistic regression analyses (Quinn and Keough 2003), one for biotic factors and one for abiotic factors, were used to determine which characteristics best predict the presence or absence of a reproductive den. Prior to final analysis, correlation analyses of all variables were performed. When variables were highly correlated, one variable was selected based on biological criteria and quality of measurement. Because of the small sample size, it was important to reduce the number 
of variables included in any one analysis. Initial analyses were conducted for each of the previously mentioned categories (prey and other carnivore detection, vegetative cover, ease of burrowing, position on the slope, variables relating to water, and variables relating to sun exposure) in order to determine important variables to include in the final analysis. A final analysis was performed for each main category (biotic and abiotic) using the previously selected variables. Absolute values for slope were used, as slope sign was indicative of change in topography from the center of the site. 


\section{RESULTS}

Fourteen reproductive dens were found between November 2008 and November 2009, two of which were active during the survey. Five (one active) were found at Monte Bello, one was found at Russian Ridge, four were found at Blue Oak Ranch Reserve, and four (one active) were found at Fort Ord (Fig. 5-7). Measurements were taken at all fourteen sites as well as each associated random site.

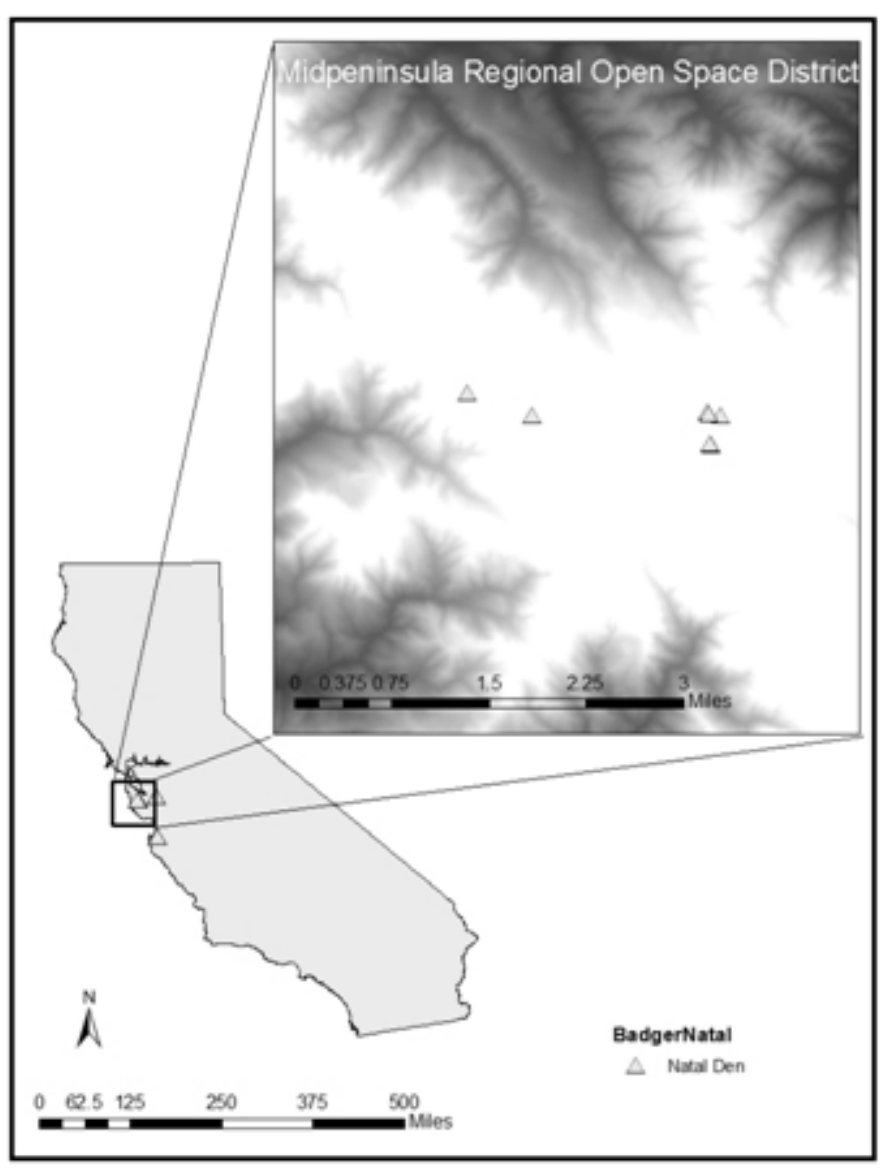

Figure 5. Midpeninsula Regional Open Space District contained six reproductive dens: five (one active) at Monte Bello and one at Russian Ridge. 


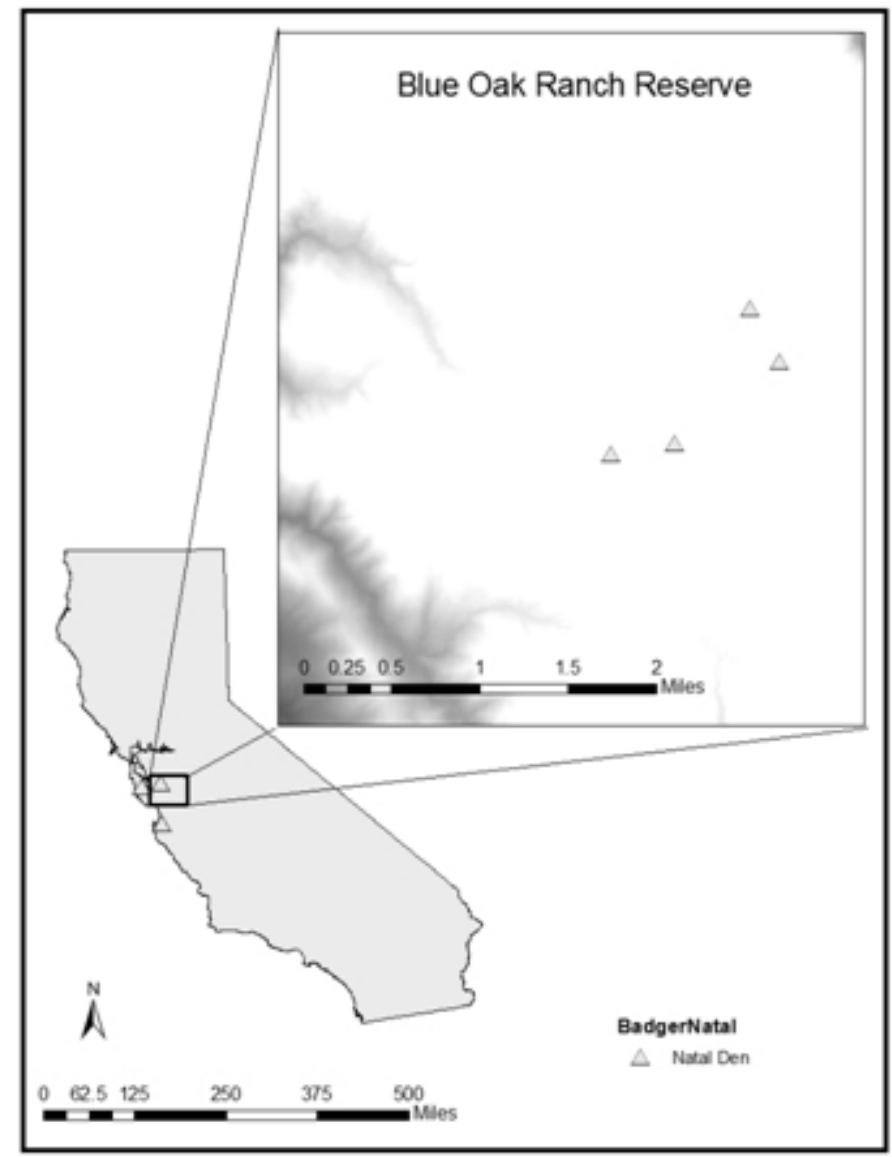

Figure 6. Blue Oak Ranch Reserve contained four reproductive dens. 


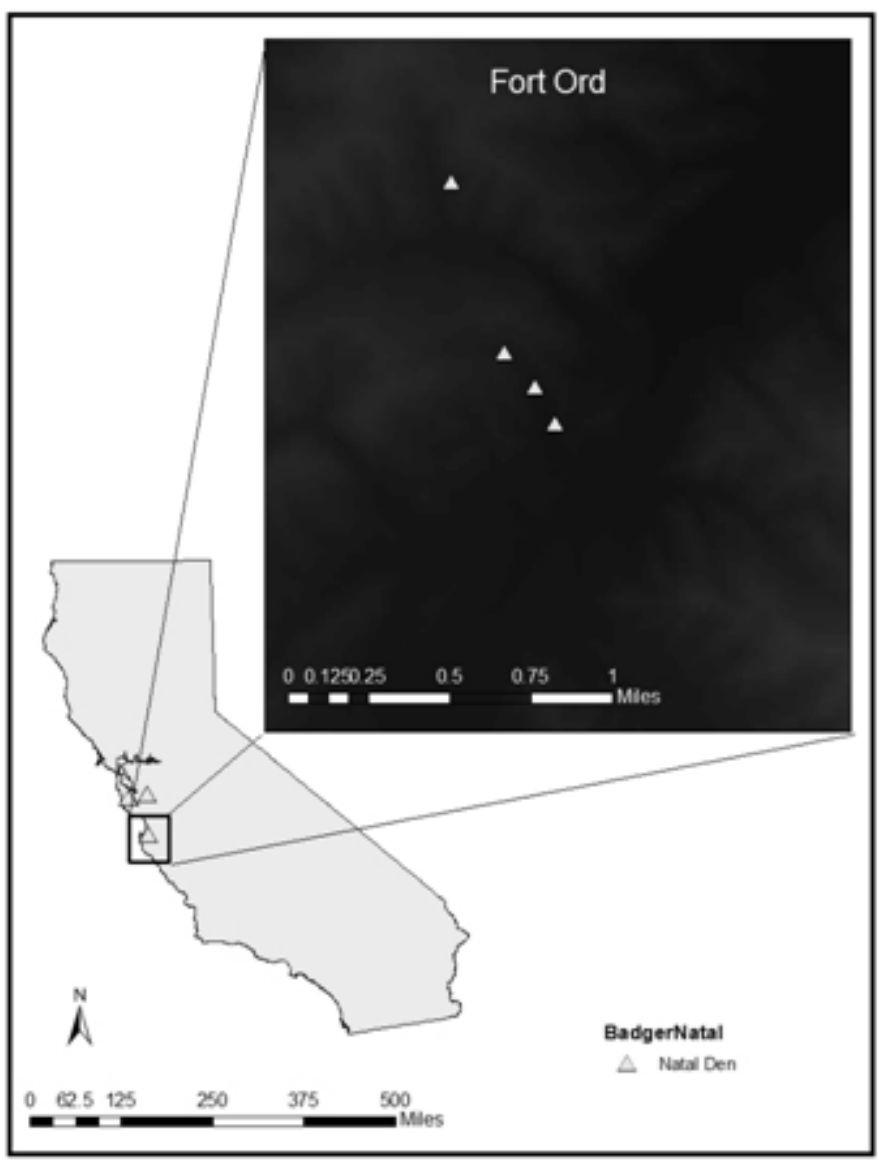

Figure 7. Fort Ord contained four (one active) reproductive dens.

The logistic regression for biotic characteristics showed extent of ground vegetation, presence of prey sign, and presence of carnivore sign were characteristics that differed between sites with reproductive dens and adjacent sites without dens. The logistic regression model for biotic characteristics was significant $(p=0.001)$ and identified several biotic variables associated with reproductive den sites. There was a relatively high association between predicted and observed data (Nagelkerke $\left.\mathrm{R}^{2}=0.636\right)$ and an overall accuracy of $85.7 \%$ (Fig. 8). At reproductive sites, the extent of ground vegetation 
between 12 and $20 \mathrm{~m}$ was less than that at non-reproductive sites $(p=0.009)$ (Fig. 9a). Prey sign density between 12 and 20 m was lower in reproductive sites than at nonreproductive sites $(p=0.017)$ (Fig. 9b). Carnivore sign was at a lesser distance in the downwind direction than at non-reproductive sites $(p=0.045)$ (Fig. 9c). Mean shrub width, by itself, was not significant $(p=0.284)$ but the hierarchical selection process included it in the final model (Fig. 9d). The final model was:

$$
p_{\text {Reproductive site }}=\frac{e^{27.306-0.041 * \text { GC12to20-0.076*DirCS- }-0.205 * \mathbf{S 1 2 t o 2 0}+0.001 * \text { Shrubwidth }}}{1+e^{27.306-0.041 * \text { GC12to20-0.076*DirCS }-0.205 * \text { PS12to20+0.001*Shrubwidth }}}
$$

where GC12to20 = ground cover 12 to $20 \mathrm{~m}$, DirCS = direction of carnivore sign (carnivore sign upwind of the den), PS12to20 = prey sign 12 to $20 \mathrm{~m}$, and Shrubwidth $=$ mean shrub width.

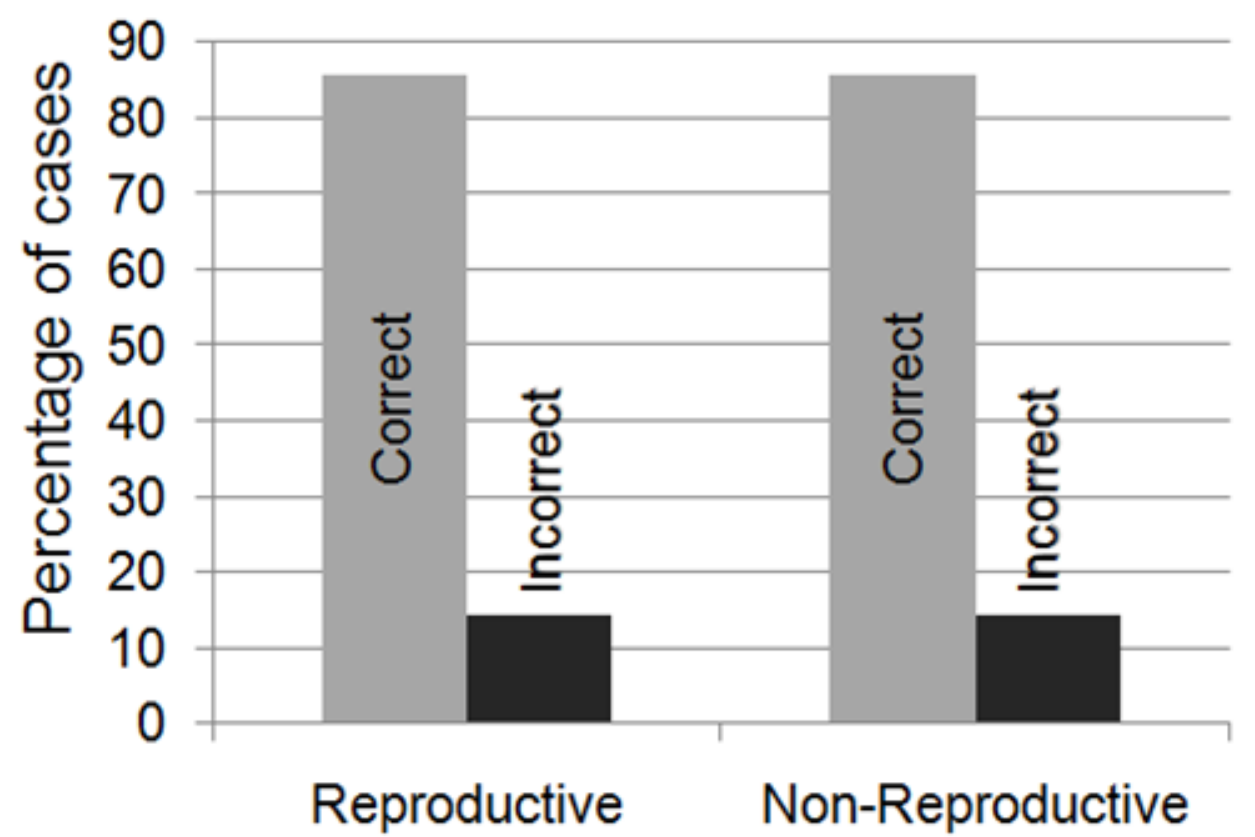

Figure 8. Logisitic regression model classification success for biotic factors: Bars represent the proportion of cases in which the model correctly predicted either a reproductive site or nonreproductive site. The overall model significance was $p=0.001$ with Nagelkerke $R^{2}=0.636$. 

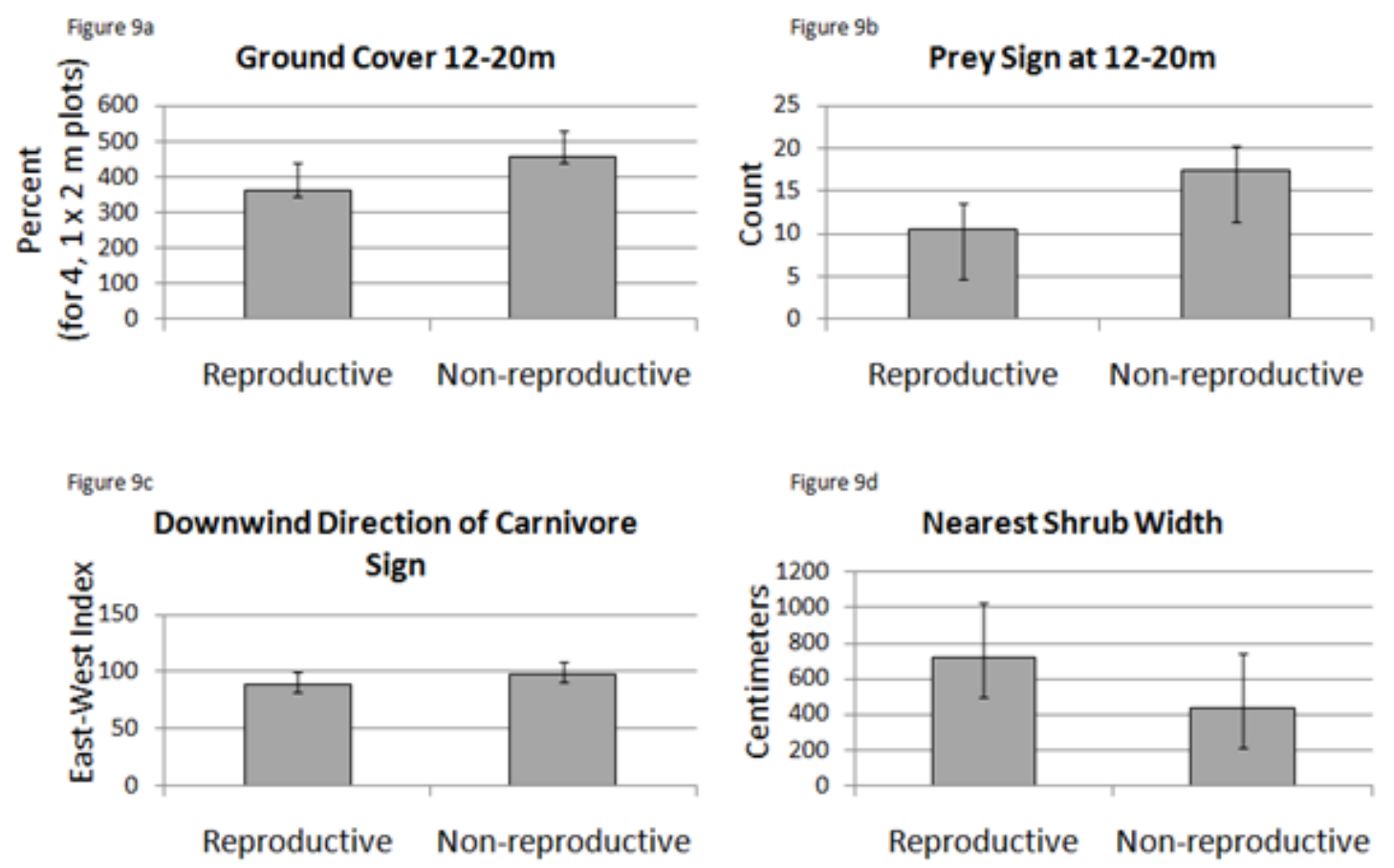

Figure 9. Mean values for biotic characteristics for reproductive and non-reproductive dens included in the logistic regression model. Error bars are $95 \%$ confidence limits. 9a. Ground cover between 12 and 20 meters from the center of the site. $9 \mathrm{~b}$. Prey sign between 12 and 20 meters from the center of the site. 9c. Downwind carnivore sign. 9d. Average shrub width.

The logistic regression model for abiotic characteristics showed distance to drainage points and slope were important abiotic predictors in classifying reproductive sites. The logistic regression model was significant (Nagelkerke $\left.\mathrm{R}^{2}=0.666, p=0.001\right)$ with an overall accuracy of $82.1 \%$ (Fig. 10). The centers of reproductive sites were closer to drainage points $(p=0.004)$ than at non-reproductive sites (Fig. 11a). At reproductive sites the absolute values of slope at $30 \mathrm{~m}$ from the center were less steep than at nonreproductive sites $(p=0.010)$ (Fig. 11b) and the absolute values of slope at $40 \mathrm{~m}$ from the center were steeper than at non-reproductive sites $(p=0.021)$ (Fig. 11c). The final model also indicated, at reproductive sites, the absolute values of slope were steeper at $10 \mathrm{~m}$ 
from the center of the site, but this variable by itself was not significant $(p=0.065)$ (Fig.

11d). The final model was:

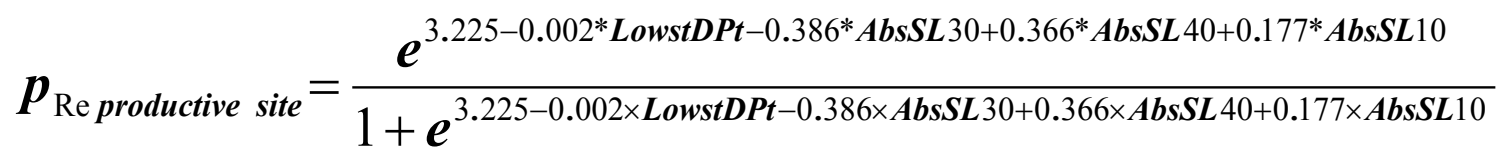

where LowstDPt $=$ distance to lowest drainage point, AbsSL30 = absolute slope at $30 \mathrm{~m}$ from the center, AbsSL40 = absolute slope at $40 \mathrm{~m}$ from the center, and AbsSL10 = absolute slope at $10 \mathrm{~m}$ from the center.

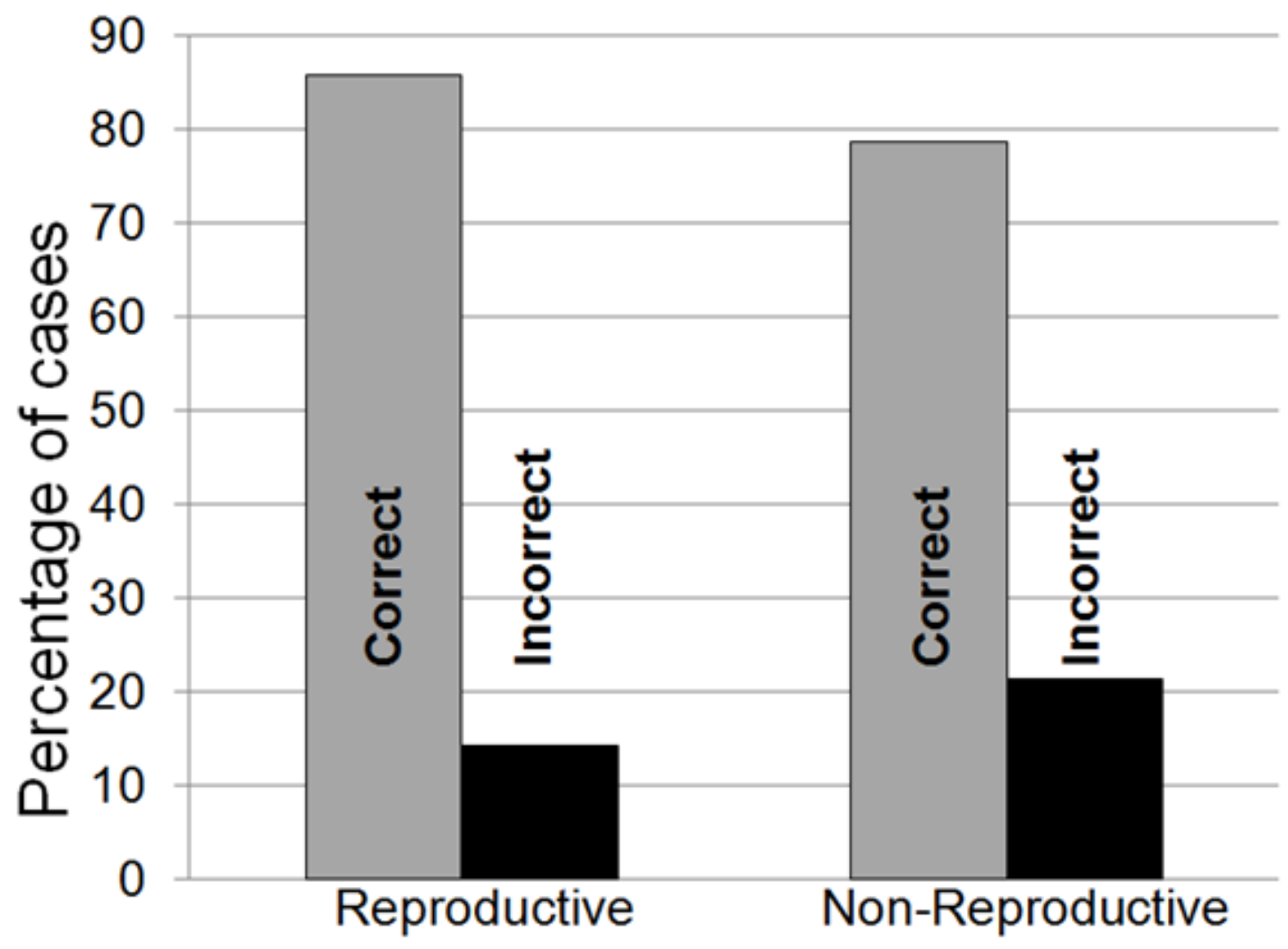

Figure 10. Logisitic regression model classification success for abiotic factors: Bars represent the proportion of cases in which the model correctly predicted either a reproductive site or nonreproductive site. The overall model significance was $p=0.001$ with Nagelkerke $R^{2}=0.666$. 


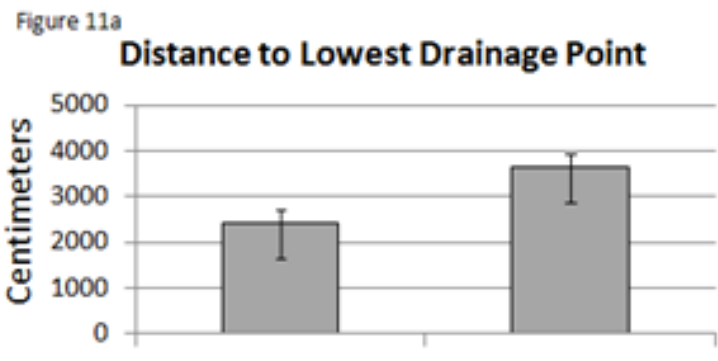

Reproductive Non-reproductive

Figure 11c

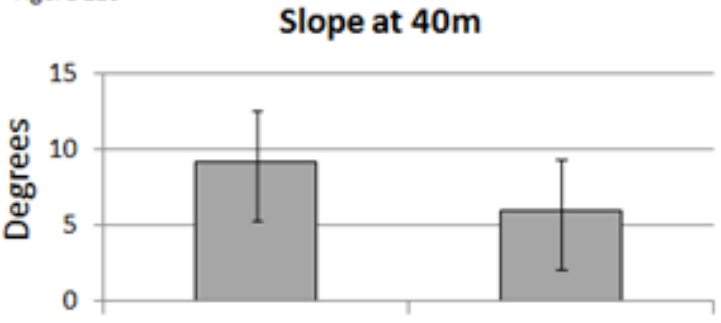

Reproductive Non-reproductive
Figure 11b

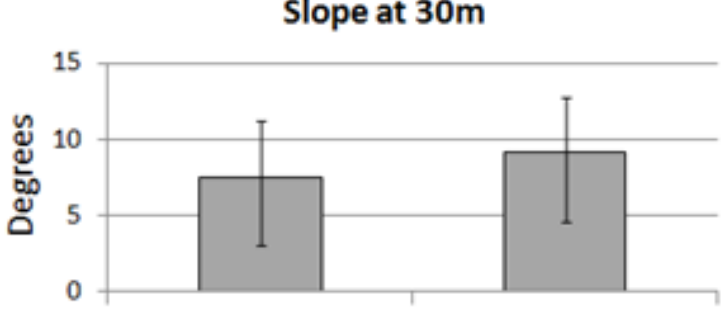

Reproductive Non-reproductive

Figure 11d

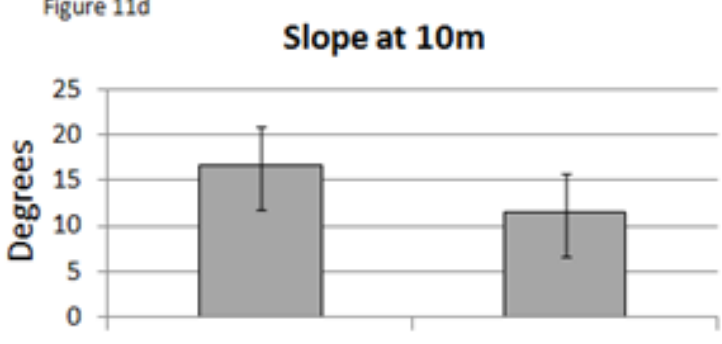

Reproductive Non-reproductive

Figure 11. Mean values for abiotic characteristics for reproductive and non-reproductive dens included in the logistic regression model. Error bars are $95 \%$ confidence limits. 11a. Distance to the nearest drainage point. 11b. Absolute value of slope at 30 meters from the center of the site. $11 \mathrm{c}$. Absolute value of slope at 40 meters from the center of the site. $11 \mathrm{~d}$. Absolute value of slope at 10 meters from the center of the site. 


\section{DISCUSSION}

This study shows that both biotic and abiotic factors are important for reproductive den site selection by the American badger within grassland habitat in central California. Other Mustelids are known to select reproductive sites based on biotic habitat characteristics; for example, Magoun \& Copeland (1998) have shown that wolverines (Gulo gulo) select reproductive sites with minimal ground cover as do river otters (Lontra canadensis) (Gorman et al. 2006). Abiotic habitat characteristics have been shown to be important for reproductive site selection; for example, sloped environments are selected as reproductive sites for river otter (Lontra canadensis) (Harris \& Ogan 1997), swift fox (Vulpes velox) (Kintigh \& Andersen 2005), and Tibetan fox (Vulpes ferrilata) (Wang et al. 2008).

This study indicates the presence of predators influences badger selection of reproductive den sites. Two different mechanisms may have been responsible for the badger reproductive dens being upwind of carnivore sign. Either female badgers selected sites in areas where they could not detect carnivores, or carnivores moved into areas where they could not be detected on the site after the badger established a den. It is unlikely female badgers would select a reproductive den site without surveying the surrounding area for potential threats to her kits, such as carnivore sign; therefore, the second mechanism is the most likely scenario. This hypothesis is supported by a recent study in Sweden regarding red and arctic fox reproductive dens (Tannerfeldt et al. 2002). In my preliminary surveys near an active coyote den, there appeared to be a lack of badger sign near the den, even when both badger and coyote sign were observed nearby. 
This observation along with that of Tannerfeldt et al. (2002) convinced me that an exclusionary factor may exist for carnivores in natal areas. Thus, the carnivore sign found in this study was more likely to occur after den excavation.

Badgers appear to select sites that provide unrestricted vision or wind movement near the entrance. Reproductive dens had less ground vegetation within $20 \mathrm{~m}$ of the center than non-reproductive sites. Badgers have poor eyesight, and less ground vegetation around the den may make it easier for the mother to maintain visual contact with her kits. Minimal ground vegetation near the den is also consistent with other mustelids that develop natal and maternal dens (Kinley \& Newhouse 2008), such as wolverines (Gulo gulo) (Magoun \& Copeland 1998) and river otters (Lontra canadensis) (Gorman et al. 2006). Although shrub size was not a significant variable by itself ( $p=$ 0.284), it added significance to the model. Its inclusion in the model makes intuitive sense because increased shrub cover may provide protection for the kits, and the shrub root system may enhance burrow stability. The topographical differences between reproductive and non-reproductive sites may also reflect predator avoidance; a less steep slope at $30 \mathrm{~m}$ away from the den entrance with a steeper slope at $10 \mathrm{~m}$ away from the den entrance may direct scent via wind to the den, providing advance warning of predator presence in the immediate area. However, additional research on shrub size, root systems, microeffects of topography, and seasonal effects on wind direction are needed for verification.

This study shows a lower prey density at reproductive sites. One of two different mechanisms may have been responsible for the lower prey densities near reproductive 
den entrances observed in this study. Either prey near the den entrance were consumed/expelled post excavation of reproductive dens, or female badgers selected den sites without high densities of prey. The first mechanism is unlikely because signs of prey density (burrows and sign) and badger foraging activity (foraging burrows and their associated soil mounds) deteriorate slowly (Eldridge 2004); therefore they should have been present in greater numbers than observed. It is more likely that mother badgers select sites with reduced prey densities in the immediate area, but within foraging distance of prey populations large enough to sustain both mother and kits. In the present study, reproductive dens tended to be within a half-kilometer of large prey populations (e.g. ground squirrels). Female badgers may select areas with lower prey to reduce possible kit predation from other carnivores foraging on the same prey population. Additional research involving kit diet and diet changes for lactating females would add important information to fundamental reproductive characteristics. Messick (1987) suggests badger kits eat insects; although insect quantity and diversity were not measured for this study, insects may be a high component of kit diet, or they may be used to practice for hunting.

The results of this study also suggest badgers select reproductive den sites based on ease of burrowing. Reproductive sites were found in areas with less steep slopes near the den entrance than further away, with steeper slopes in the immediate area of the den entrance than points further from the den, and with the lowest drainage point being relatively near the burrow. It is important for natal areas of river otter (Lontra canadensis) (Harris \& Ogan 1997), swift fox (Vulpes velox) (Kintigh \& Andersen 2005), 
and Tibetan fox (Vulpes ferrilata) (Wang et al. 2008) to be located on a slope. Although all sites in this study were located on slopes, this research showed an increase in steepness occurring near reproductive den entrances. Selecting a den site near the lowest drainage point may relate more to soil type and topography than to water flow. The soil may be more preferable at sites within a drainage, as fine soils will be washed downhill. The advantages of selecting a reproductive site with a steeper slope close to the den entrance, relative to further away, may be to provide an easier digging angle, a flatter place for kits, and to enhance the mother's visual distance. A less steep slope at $30 \mathrm{~m}$ away from the den entrance with the actual entrance having a steeper slope may direct scent via wind to the den, providing advance warning of predator presence in the immediate area.

Future research on reproductive den habitat requirements should investigate the role of access to water and prey outside of the $40 \mathrm{~m}$ radius scale and the sensory distance of badgers. It is unknown if badgers require water for hydration or if they obtain water from their prey. If they must drink water, then the distance to a water source further than $40 \mathrm{~m}$ from the reproductive den may be an important component to reproductive habitat. The sensory distance of badgers has yet to be determined; it may vary with topography, wind direction and intensity, habitat type, and individual ability. If the sensory distance and sensitivities of badgers were better understood, then a more accurate model may be produced for reproductive den site selection.

A possible conservation strategy for American badgers should identify potential habitats using GIS models of large scale habitat characteristics, with further site selection 
based on smaller scale habitat measurements identified by this study. Presence or absence of grassland and landform characteristics could produce a GIS habitat suitability map. Habitat suitability maps produced in GIS have been used for a wide array of studies and conservation efforts; black bear (Van Manen \& Pelton 1992), black terns (Naugle et al. 2000), Florida scrub jays (Breininger et al. 1998), pygmy rabbits (Gabler et al.2000), Eurasian lynx (Schadt et al. 2002), Andean bears (Peralvo et al. 2005), Sonoran pronghorn (O'Brien et al. 2005), and Indiana bats (Watrous et al. 2006) have all benefited from habitat suitability models. Badger reproductive den characteristics that should be included in a GIS model include distance to lowest drainage points, slope, and grassland habitats. Fine scale measurements of ground vegetation, local soil penetrability and local slope patterns would be used as further selection criteria. Once suitable habitat is identified, the ownership of that habitat and its associated corridors should be determined, and either land acquisition or property owner education should commence. It is important to keep in mind that reproductive habitat may differ from core habitat and corridor habitat. All three types of habitat need to be present and linked for a sustainable reproductive population. Corridor habitat is undescribed for badgers at this time, although Messick (1987) has suggested juvenile badgers use different corridor habitat than adults, Quinn (2008) suggested movement habitat and denning habitat can be different, and Diamond (unpublished data) has suggested road kill locations correlate with slopes of 5-15\%, loamy soils, and sagebrush. All three habitat types should be assessed appropriately prior to land acquisition. 
By implementing conservation practices using this model, other species may also be conserved. Many plants and animals benefit from digging activities of badgers. Badgers are bioturbators, mixing lower with upper level soils, creating soil genesis (Scobie 2002), promoting the formation of humus and creating different soil environments than the surrounding areas, which may lead to islands of plant diversity on old badger mounds (Sullivan 1996). Many animals use abandoned badger burrows as day-use cover, to escape from danger, and for nesting and overwintering dens (Scobie 2002). Burrowing owls inhabit badger burrows (Rich 1984; Rich 1986; Desmond \& Savidge 1996; Belthoff \& King 2002; Scobie 2002). Breeding density and nesting success of burrowing owls in some systems are dependent on availability of badger burrows (Holmes et al. 2003; Green \& Anthony 1989). Jack rabbits use badger burrows as escape burrows (West 1961). Swift foxes and snakes also use badger burrows (Scobie 2002). By using this model to designate appropriate habitat, conserving badger reproductive habitat may also conserve habitat for these species. 


\section{LITERATURE CITED}

Anderson, D. C. and D. W. Johns. 1977. Predation by badger on yellow-bellied marmot in Colorado. The Southwestern Naturalist 22(2):283-284.

Azevedo, F. C. C., V. Lester, W. Gorsuch, S. Lariviere, A. J. Wirsing, and D. L. Murray. 2006. Dietary breadth and overlap among five sympatric prairie carnivores. Journal of Zoology 269:127-135.

Belthoff, J. R. and A. King. 2002. Nest-site characteristics of burrowing owls (Athene cunicularia) in the Snake River Birds of Prey National Conservation Area, Idaho, and applications to artificial burrow installation. Western North American Naturalist 62(1):112-119.

Breininger, D. R., V. L. Larson, B. W. Duncan, and R. B. Smith. 1998. Linking habitat suitability to demographic success in Florida scrub-jays. Wildlife Society Bulletin 26(1):118-128.

Desmond, M. J. and J. A. Savidge. 1996. Factors influencing burrowing owl (Speotyto cunicularia) nest densities and numbers in western Nebraska. American Midland Naturalist 136(1):143-148.

Fernandez, J. A., F. A. Cervantes, and M. del Carmen Corona Vargas. 2007. New distributional records for mammals from Tlaxcala, Mexico. The Southwestern Naturalist 52(2):328-333.

Gabler, K. I., J. W. Laundré, and L. T. Heady. 2000. Predicting the suitability of habitat in southeast Idaho for pygmy rabbits. Journal of Wildlife Management 64(3):759764.

Goodrich, J. M. and S. W. Buskirk. 1998. Spacing and ecology of North American badgers (Taxidea taxus) in a prairie-dog (Cynomys leucurus) complex. Journal of Mammalogy 79(1):171-179.

Gorman, T. A., J. D. Erb, B. R. McMillan, D. J. Martin, and J. A. Homyack. 2006. Site characteristics of river otter (Lontra canadensis) natal dens in Minnesota. American Midland Naturalist 156:109-117.

Green, G. A. and R. G. Anthony. 1989. Nesting success and habitat relationships of burrowing owls in the Columbia Basin, Oregon. The Condor 91(2):347-354.

Harris, J. E., and C. V. Ogan., Eds. 1997. Mesocarnivores of northern California: biology, management, and survey techniques, workshop manual. August 12-15, 1997, Humboldt State University, Arcata, CA. The Wildlife Society, California North Coast Chapter, Arcata, CA, 127 pp. 
Hein, E. W. and W. F. Andelt. 1995. Evaluations of indices of abundance for and unexploited badger population. The Southwestern Naturalist 40(3):288-292.

Holmes, A. L., G. A. Green, R. L. Morgan, and K. B. Livezey. 2003. Burrowing owl nest success and burrow longevity in north central Oregon. Western North American Naturalist 63(2):244-250.

Hoodicoff, C. S. 2003. Ecology of the badger (Taxidea taxus) in the Thompson Region of British Columbia: impacts for conservation. Masters of Science Thesis, University of Victoria.

Jager, H. I., E. A. Carr, and R. A. Efroymson. 2006. Simulated effects of habitat loss and fragmentation on a solitary mustelid predator. Ecological Modeling 191:416-430.

Kinley, T. A. and N. J. Newhouse. 2008. Ecology and translocation-aided recovery of an endangered badger population. Journal of Wildlife Management 72(1):133-122.

Kintigh, K. M. and M. C. Andersen. 2005. A den centered analysis of swift fox habitat characteristics in northeastern New Mexico. American Midland Naturalist 154 (1):229-239.

Krebs, C. J. 1999. Ecological methodology; second edition. Addison-Welsey Educational Publishers, Inc., Menlo Park, California, 168-184 pp.

Lariviere, S. and F. Messier. 1998. Denning ecology of the striped skunk in the Canadian prairies: implications for waterfowl nest predation. The Journal of Applied Ecology 35(2):207-213.

Lay, C. 2008. The status of the American badger in the San Francisco Bay area. Thesis, San Jose State University.

Lindzey, F. G. 1976. Characteristics of the natal den of the badger. Northwest Science 50(3):178-180.

Lindzey, F. G. 1978. Movement patterns of badgers in northwestern Utah. Journal of Wildlife Management 42(2):418-422.

Long, C. A. 1973. Taxidea taxus. Mammalian species No. 26. The American Society of Mammalogists, 1-4 pp.

Magoun, A. J. and J. P. Copeland. 1998. Characteristics of wolverine reproductive den sites. Journal of Wildlife Management 62(4):1313-1320.

Messick, J. P. 1987. North American Badger. In: Wild furbearer management and conservation in North America. Ontario Trappers Association and Ontario Ministry of Natural Resources, Toronto, 586-597 pp. 
Michener, G. R. 2004. Hunting techniques and tool use by North American badgers preying on Richardson's ground squirrels. Journal of Mammalogy 85(5): 10191027.

Minta, S. C., K. A. Minta, and Dale F. Lott. 1992. Hunting associations between badgers (Taxidea taxus) and coyotes (Canis latrans). Journal of Mammalogy 73(4):814820.

Murie, J. O. 1992. Predation by badgers on Columbian ground squirrels. Journal of Mammalogy 73(2):385-394.

Naugle, D. E., K. F. Higgins, M. E. Estey, R. R. Johnson, and S. M. Nusser. 2000. Local and landscape-level factors influencing black tern habitat suitability. Journal of Wildlife Management 64(1):253-260.

O'Brien, C. S., S. S. Rosenstock, J. J. Hervert, J. L. Bright, and S. R. Boe. 2005. Landscape-level models of potential habitat for Sonoran pronghorn. Wildlife Society Bulletin 33(1):24-34.

Peralvo, M. F., F. Cuesta, and F. Van Manen. 2005. Delineating priority habitat areas for the conservation of Andean bears in northern Ecuador. Ursus 16(2):222-233.

Quinn, J. H. 2008. The ecology of the American badger Taxidea taxus in California: assessing conservation needs on multiple scales. Dissertation, University of California at Davis.

Quinn, G. P. and M. J. Keough. 2003. Experimental design and data analysis for biologists. Cambridge University Press, New York, 78-106 pp.

Rich, T. 1984. Monitoring burrowing owl populations: implications of burrow re-use. Wildlife Society Bulletin 12(2):178-180.

Rich, T. 1986. Habitat and nest-site selection by burrowing owls in the sagebrush steppe of Idaho. Journal of Wildlife Management 50(4):548-555.

Sargeant, A. B. and D. W. Warner. 1972. Movements and denning habits of a badger. Journal of Mammalogy 53(1):207-210.

Schadt, S., et al. 2002. Assessing the suitability of central European landscapes for the reintroduction of Eurasian lynx. Ecology 39:189-203.

Scobie, D. 2002. Status of the American badger (Taxidea taxus) in Alberta. Alberta Wildlife Status Report No. 43. 
Sullivan, J. 1996. Wildlife species: Taxidea taxus. In: Fire effects information system, [online]. U. S. Department of Agriculture, Forest Service, Rocky Mountain Research Station, Fire Sciences Laboratory. Available from http://www.fs.fed.us/database/feis/ (accessed June 2005).

Van Manen, F. T. and M. R. Pelton. 1992. Procedures to enhance the success of a black bear reintroduction program. Bears: their biology and management. International Conference on Bear Research and Management, Grenoble, France 9(2):67-77.

Verbeek, N. A. M. 1965. Predation by badger on yellow-bellied marmot in Wyoming. Journal of Mammalogy 46(3):506-507.

Verts, B. J. and L. N. Carraway. 1998. Land mammals of Oregon. University of California Press, Berkeley and Los Angeles, California, 428-433 pp.

Wang, Z., X. Wang, and A. A. Chmura. 2008. Den habitat characteristics of Tibetan foxes vulpes ferrilata in Shiqu County, Sichuan Province, China. Zoological Studies 47(4):445-454.

Waser, P. M. and W. T. Jones. 1983. Natal philopatry among solitary mammals. The Quarterly Review of Biology 58(3):355-390.

Watrous, K. S., T. M. Donovan, R. M. Mickey, S. R. Darling, A. C. Hicks, and S. L. Von Oettingen. 2006. Predicting minimum habitat characteristics for the Indiana bat in the Champlain Valley. Journal of Wildlife Management 70(5):1228-1237.

Weir, R. and C. Hoodicoff. 2002. Development of conservation strategies for badgers in the Thompson \& Okanagan Regions: 2001-02 Annual Report Year 3 of 4. Artemis Wildlife Consultants.

West, R. R., M. H. Bartel, and M. L. Plenert. 1961. Use of forms by the black-tailed jack rabbit in southwestern Kansas. Transactions of the Kansas Academy of Science (1903-) 64(4):344-348.

Williams, D. F. 1986. Mammalian species of concern in California. California Department of Fish and Game Report 86-1. California Department of Fish and Game, Sacramento, CA. 